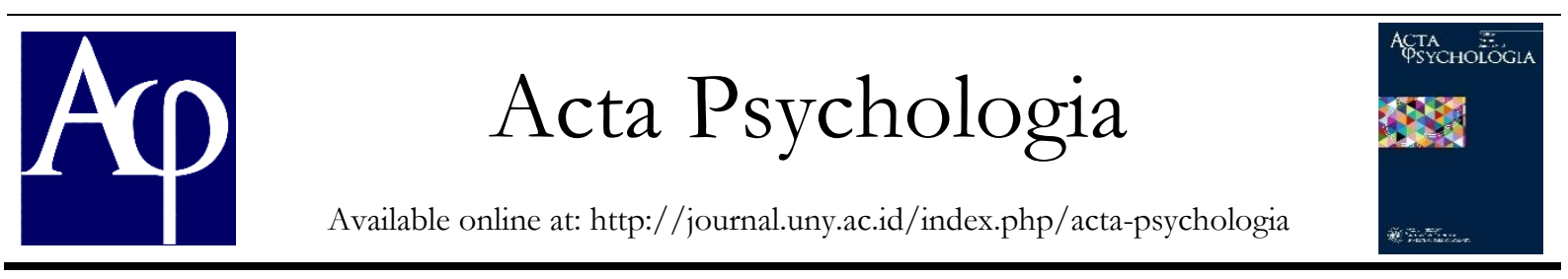

\title{
Dinamika Psikologis pada Lansia Dilihat dari Sisi Romantic Relationship Setelah Melakukan Perkawinan di Usia Lanjut
}

\author{
Cynthia Ayu Oktariza, Siti Rohmah Nurbayati \\ Program Studi Psikologi, Universitas Negeri Yogyakarta; Jl. Colombo No. 1 Sleman Yogyakarta, \\ 55281 \\ cynthia.ayu2016@student.uny.ac.id
}

\begin{abstract}
Abstrak
Penelitian ini bertujuan untuk mengetahui dinamika psikologis pada lansia setelah melakukan perkawinan di usia lanjut melalui komponen hubungan romantis yang muncul. Penelitian ini mengggunakan metode kualititaif dengan pendekatan fenomenologis. Subjek penelitian adalah lansia dengan kriteria berusia 60 tahun ke atas dan pernah melakukan perkawinan di usia lanjut. Penelitian ini menunjukkan komponen hubungan romantis yang muncul berupa, keintiman, hasrat, komitmen, harapan, penerimaan diri positif, dan munculnya masalah. Dua dari tiga pasangan yang menjadi responden menyatakan melalui proses kencan sebelum melakukan perkawinan. Perkawinan di usia lanjut identik dengan membutuhkan teman atau pendamping hidup di hari tua dengan saling berbagi perhatian, merawat, dan memenuhi kebutuhan atau keperluan pasangan serta menjalin persahabatan. Dua dari tiga pasangan masih membutuhkan proses penyesuaian untuk membangun kepercayaan dan menciptakan komunikasi yang intim. Hubungan seksual tidak menjadi kebutuhan pokok dan hal penting dalam perkawinan di usia lanjut. Lebih berbagi mengenai kebahagiaan dan kurang adanya keterbukaan mengenai masalah pribadi. Terdapat pula perbedaan orientasi perkawinan pada lansia laki-laki dengan lansia perempuan.
\end{abstract}

Kata Kunci: dinamika psikologis, lansia, bubungan romantis, perkawinan

\begin{abstract}
This study aimed to describe or find out how the psychological dynamics of the elderly were seen from the side of romantic relationship after marriage in old age through the emerging components of romantic relationship. This study used qualitative methods with a phenomenological approach. The subjects of this study were elderly with the criteria aged 60 years an over and had been marriage in old age. This study showed through the components of romantic relationship that appear, there were intimacy, desire, commitment, hope, positive self-acceptance, and problem arises. Two of three elderly couples who were respondents through a dating process before married. Marriage in old age was related to the needs of friends or life companions in old age by sharing the attention, caring, and fulfilled the needs of the couple. Two of three elderly couples still need an adjustment process to build trust and create intimate communication. Sex relationship was not a major need and not really important for marriage in old age. Elderly marriage prefer to shared happiness and less openness about personal matters. There were also a differences in marital orientation between elderly men and women.
\end{abstract}

Keywords: psychological dynamic, elderly, romantic relationship, marriage.

\section{Pendahuluan}

Setiap makhluk hidup akan mengalami proses menua. Menurut Caselli dan Lopez (dalam Suardiman, 2011: 1) menua atau aging merupakan fase perubahan biologis yang dialami oleh setiap makhluk hidup secara terus menerus. Tahap akhir dari fase penuaan biasanya disebut sebagai lanjut usia atau lansia. Pada umumnya batasan usia lanjut bervariasi diberbagai negara. Menurut Yung, dkk (2016: 2) batasan usia lanjut dimulai pada usia 45 hingga 65 tahun ke atas. 
Menurut Kemenkes RI Pusat Data dan Informasi (2017) diperkirakan pada tahun 2017 terdapat 23,66 juta penduduk lansia di Indonesia (9,03\%). Penduduk lansia di Indonesia diprediksi meningkat pada tiap tahun, pada tahun $2020(27,08$ juta), tahun 2025 (33,69 juta) tahun 2030 (40,95 juta) dan tahun 2035 (48,19 juta). Data tersebut menunjukkan bahwa secara global Indonesia dari tahun 2015 sudah memasuki era penduduk menua (ageing population) karena jumlah penduduk yang berusia 60 tahun ke atas melebihi angka $7 \%$.

Yogyakarta sendiri menurut Badan Pusat Statistik (2017) menempati urutan pertama provinsi yang memiliki prevalensi tertinggi penduduk usia tua mencapai 13,90\%. Menurut Soeweno suatu negara dikatakan berstruktur tua jika mempunyai populasi lansia di atas 7\% (Kemenkes RI, 2017). Pertambahan jumlah lansia tersebut memungkinkan munculnya berbagai permasalahan bagi lansia, seperti kehilangan pekerjaan, kehilangan tujuan hidup, resiko terkena penyakit, kehilangan teman, kehilangan pasangan yang dalam hal ini menjadikan lansia terisolasi dan merasa kesepian (Berlian \& Heppy, 2014).

Menurut Suardiman (2011: 3) rasa kesepian yang dialami oleh lansia disebabkan karena adanya perasaan kehilangan akibat terputusnya hubungan sosial dengan kerabat atau teman, hal tersebut dapat membawa pada rasa kehilangan, tersisih, dan terpencil. Pada masa lanjut usia sangat penting mengutamakan kebutuhan psikologisnya, salah satunya ialah kebutuhan akan rasa memiliki, dimiliki, dan rasa kasih sayang (the belongingness and love needs) (Suardiman, 2016: 15). Kebutuhan tersebut dapat berasal dari lingkungan sosialnya baik keluarga, teman dekat, atau pun pasangannya.

Kebutuhan akan rasa memiliki, dimiliki, dan rasa kasih sayang sangat dibutuhkan bagi lansia dalam menikmati masa tuanya. Adapun kesendirian merupakan aspek yang menjadikan hidup lansia rentan akan berbagai masalah psikologis tertutama kesepian yang dapat menjadikan lansia stress hingga depresi. Kesendirian yang dialami oleh lansia dapat berasal dari beberapa faktor, salah satunya ialah kematian pasangan atau tidak adanya pasangan hidup. Manusia memiliki suatu kebutuhan yang biasa disebut need to belong yaitu menjalin hubungan yang erat dan saling memberdayakan antara satu dengan yang lain (Myers, 2012:119). Manusia akan merasa lebih bahagia dan berguna apabila hidupnya dibutuhkan oleh orang lain.

Perkawinan sendiri diharapkan
dapat menjadi kunci pemenuhan kebutuhan psikologis dan mengatasi kesepian pada lansia. Melalui perkawinan meskipun di usia lanjut, lansia menjadi memiliki rekan sepenanggungan dalam menjalani hari tua dan tidak merasakan kesendirian bahkan kesepian. Biasanya sebelum dan setelah menjalin hubungan perkawinan, individu akan merasakan adanya hubungan romantis dengan pasangan. Erickson (dalam Papalia, Olds \& Feldman, 2007) mengatakan bahwa mengembangkan hubungan yang intim dan romantis pada dasarnya merupakan salah satu tugas perkembangan pada masa dewasa awal.

Hubungan romantis berkaitan dengan adanya bentuk cinta, kasih sayang, penerimaan, komitmen, dan kesetiaan terhadap pasangannya. Spanier (dalam De Munck, 1998) juga mendefinisikan hubungan romantis sebagai sebuah keinginan umum individu terhadap rasa cinta, perkawinan, keluarga dan suatu hubungan yang melibatkan interkasi antara laki-laki dan perempuan. Sternberg (1997) memandang hubungan romantis berisikan tiga komponen yang meliputi keintiman, hasrat, dan komitmen.

Menurut hasil penelitian yang dilakukan oleh Putri (2017: 11) hubungan romantis yang muncul pada perkawinan pasangan lansia ialah berupa adanya perhatian dan komitmen yang diberikan 
oleh pasangan. Menciptakan hubungan romantis menuntut individu untuk dapat memahami dan mengerti kebutuhan, keinginan, mapun kondisi pasangannya, dengan begitu hubungan romantis yang tercipta dapat berkualitas.

Pada lain sisi lansia biasanya mengalami perubahan karakteristik yang bertolak belakang dengan pemenuhan kebtuhan hubungan romantis dalam perkawinan, seperti kondisi fisik, kognitif, psikis, maupun sosioemosi yang cenderung menurun. Menurut Suardiman (2011: 37) penurunan fisik pada lansia berupa fungsi sensifitas dan efisiensi organ alat indera yang menurun, organ reproduksi juga akan menurun, dan menurunnya kecepatan motorik, sehingga reaksi dan koordinasi gerak terkesan lamban. Suardiman (2011: 67) juga menyebutkan bahwa seorang lansia akan mengalami kesulitan dengan fungsi ingatan atau dalam mengekspresikan secara verbal. Hal ini menjadikan lansia dianggap oleh masyarakat umum termasuk keluarga lansia sendiri sebagai usia degenarasi yang disertai dengan berbagai penyakit, selain itu lansia juga dianggap tidak mudah jatuh cinta dan tidak memiliki gairah seksual pada lawan jenis (Syah \& Mulyadi, 2016: 47). Oleh sebab itu tidak jarang apabila terdapat lansia yang akan menikah di usia lanjut terhalang oleh restu dari anak maupun keluarga besar, karena hal tersebut dianggap akan mendatangkan masalah baru bagi lansia apabila tidak dapat menyesuaikan hubungan perkawinan dengan pasangannya.

Namun di lain sisi melakukan perkawinan dan menjalin hubungan romantis di usia lanjut dapat mengatasi permasalahan yang sering dialami oleh lansia yaitu kesepian dan kesendirian. Permasalahan tersebut apabila tidak ditangani dengan baik dapat menjadikan lansia mengalami stress hingga depresi. Oleh karena itu perlunya memahami dinamika psikologis lansia dilihat dari sisi hubungan romantis setelah melakukan perkawinan di usia lanjut. Dinamika psikologis yang ditemukan diharapkan dapat membantu pihak keluarga maupun BKL (Bina Keluarga Lansia) dalam mengantisipasi kemungkinan konflik keluarga atau pun konflik sosial yang akan terjadi, sehingga keluarga dari pihak lansia dapat membantu dalam mensejahterakan kehidupan lansia.

\section{Metode Penelitian}

Penelitian ini menggunakan jenis penelitian kualitatif dengan pendekatan fenomenologi. Penelitian ini dilakukan di kediaman subjek yang berlokasi di Daerah Istimewa Yogyakarta. Waktu penelitian dilakukan selama kurang lebih satu bulan dan di mulai pada tanggal 6 Februari 2020 hingga 2 Maret 2020. Subjek penelitian ini adalah 6 orang lansia atau 3 pasang suami istri berusia lanjut (lansia). Keenam subjek tersebut yaitu SG dan NS (pasangan pertama), J dan BJ (pasangan kedua), SN dan TT (pasangan ketiga). Subjek pada penelitian ini memiliki pengalaman melakukan perkawinan di usia lanjut. Subjek didapatkan dengan teknik purposive sampling. Penelitian ini terdiri dari beberapa tahap. Tahap pertama memperkenalkan diri dan menginformasikan tujuan penelitian kepada ketiga pasangan yang menjadi subjek penelitian. Tahap kedua adalah melakukan wawancara mendalam. Wawancara dilakukan dengan menggunakan pedoman wawancara yang telah disiapkan. Tahap selanjutnya peneliti melakukan probing.

\section{Data, Intrumen, dan Teknik Pengumpulan Data}

Data diperoleh langsung dari subjek penelitian. Data tersebut diperoleh melalui wawancara mendalam dengan suami maupun istri pada tiap pasangan lansia yang melakukan perkawinan di usia lanjut. Adapun instrumen yang digunakan adalah peneliti itu sendiri, pedoman wawancara, dan perekam suara. Masing-masing subjek 
diwawancara kurang lebih dua kali untuk mendapatkan informasi yang selengkaplengkapnya.

Teknik analisis data yang digunakan dalam penelitian ini adalah Interpretative Phenomenological Analysis (IPA). Interpretative Phenomenological Analysis (IPA) adalah pendekatan kualitatif yang memiliki tujuan untuk memberikan pemeriksaan rinci terhadap pengalaman hidup subjek yang sedang diteliti (Smith, dkk., 2009).

\section{Hasil Penelitian dan Pembahasan}

Berdasarkan hasil analisis menunjukkan munculnya komponen hubungan romantis pada perkawinan di usia lanjut sebagai berikut.

Tabel 1. Komponen dan Elemen Hubungan Romantis yang Muncul pada Pasangan 1

\begin{tabular}{|l|l|}
\hline \multicolumn{1}{|c|}{$\begin{array}{l}\text { Komponen \& } \\
\text { Elemen }\end{array}$} & \multicolumn{2}{|c|}{ Keterangan } \\
\hline $\begin{array}{l}\text { Keintiman } \\
\text { (meningkatkan } \\
\text { kesejahteraan } \\
\text { pasangan) }\end{array}$ & $\begin{array}{l}\text { Suami } \\
\text { memberikan } \\
\text { warisan kepada } \\
\text { istri } \\
\text { Istri menyiapkan } \\
\text { keperluan dan } \\
\text { kebutuhan sehari- } \\
\text { hari suami }\end{array}$ \\
\hline $\begin{array}{l}\text { Keintiman } \\
\text { (merasakan } \\
\text { adanya } \\
\text { kesenangan dan } \\
\text { kegembiraan) }\end{array}$ & $\begin{array}{l}\text { Istri sering } \\
\text { mendapat } \\
\text { perlakuan } \\
\text { romantis seperti } \\
\text { dibelikan bunga } \\
\text { favorit oleh suami } \\
\text { dan dipuji } \\
\text { kecantikannya }\end{array}$ \\
\hline $\begin{array}{l}\text { Keintiman } \\
\text { (mampu } \\
\text { menghormati } \\
\text { pasangan) }\end{array}$ & $\begin{array}{l}\text { Istri tetap patuh } \\
\text { dan berada di sisi } \\
\text { suami Ketika } \\
\text { diminta untuk } \\
\text { berpisah dan } \\
\text { bercerai oleh sang } \\
\text { anak } \\
\text { Suami } \\
\text { mengenalkan istri } \\
\text { kepada }\end{array}$ \\
\hline
\end{tabular}

\begin{tabular}{|c|c|}
\hline & $\begin{array}{l}\text { kerabatnya dan } \\
\text { mengumumkan } \\
\text { sudah menikah. } \\
\text { Hal ini dilakukan } \\
\text { untuk } \\
\text { menghindari } \\
\text { fitnah dari orang } \\
\text { lain yang belum } \\
\text { mengetahui } \\
\text { perkawinannya }\end{array}$ \\
\hline $\begin{array}{l}\text { Keintiman } \\
\text { (mampu } \\
\text { memahami } \\
\text { kelebihan dan } \\
\text { kelemahan } \\
\text { pasangan) }\end{array}$ & $\begin{array}{l}\text { - Menurut suami, } \\
\text { kelebihan istrinya } \\
\text { sangat pintar } \\
\text { memasak, } \\
\text { kelemahannya } \\
\text { mudah } \\
\text { memikirkan } \\
\text { ucapan buruk } \\
\text { orang lain yang } \\
\text { menjelekkan } \\
\text { istrinya. istri, } \\
\text { Menurut suami } \\
\text { kelebihan tidak } \\
\text { adalah orang } \\
\text { mudah dendam } \\
\text { kepada orang } \\
\text { yang berusaha } \\
\text { menjatuhkan } \\
\text { suaminya } \\
\text { sedangkan } \\
\text { kelemahannya } \\
\text { adalah mudah } \\
\text { cemburu apabila } \\
\text { istri melakukan } \\
\text { komunikasi } \\
\text { dengan teman } \\
\text { laki-laki lain. }\end{array}$ \\
\hline $\begin{array}{l}\text { Keintiman } \\
\text { (membagi waktu } \\
\text { dan harta) }\end{array}$ & $\begin{array}{l}\text { - Suami } \\
\text { memberikan } \\
\text { seluruh uang } \\
\text { pensiunan kepada } \\
\text { istri } \\
\text { - Suami } \\
\text { memberikan } \\
\text { warisan kepada } \\
\text { istri } \\
\text { - Sering } \\
\text { meluangkan }\end{array}$ \\
\hline
\end{tabular}




\begin{tabular}{|c|c|}
\hline & $\begin{array}{ll}\text { waktu untuk } \\
\text { bepergian } \\
\text { bersama }\end{array}$ \\
\hline $\begin{array}{l}\text { Hasrat } \\
\text { (hasrat untuk } \\
\text { bersatu) }\end{array}$ & 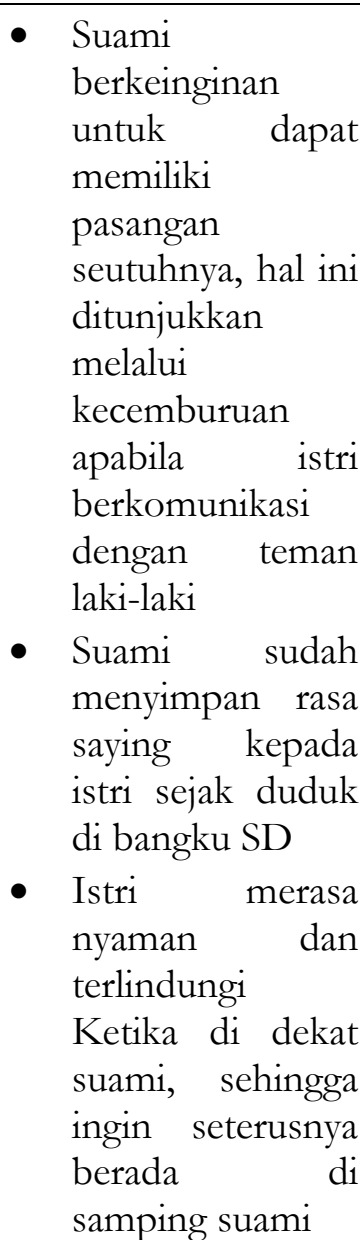 \\
\hline $\begin{array}{l}\text { Hasrat } \\
\text { (hubungan } \\
\text { seksual) }\end{array}$ & 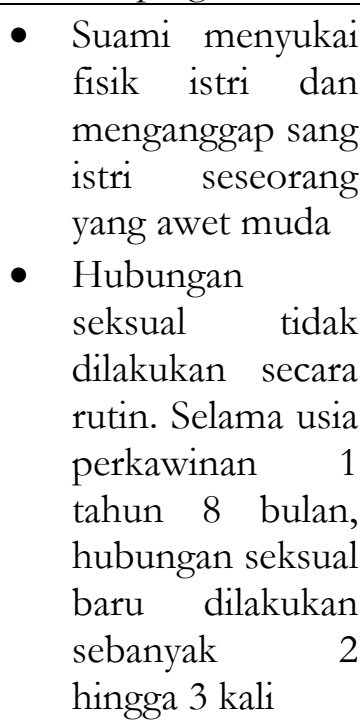 \\
\hline $\begin{array}{l}\text { Komitmen } \\
\text { jangka pendek }\end{array}$ & 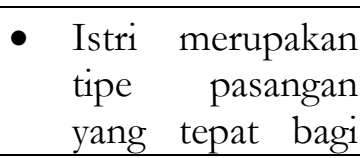 \\
\hline
\end{tabular}

\begin{tabular}{|c|c|}
\hline $\begin{array}{l}\text { (dorongan } \\
\text { menjalin } \\
\text { hubungan } \\
\text { perkawinan dan } \\
\text { alasana memilih } \\
\text { pasangan sebagai } \\
\text { pendamping } \\
\text { hidup) }\end{array}$ & $\begin{array}{l}\text { suami. Istri selalu } \\
\text { paham dan } \\
\text { mengerti maksud } \\
\text { suami tanpa } \\
\text { suami harus } \\
\text { menjelaskan } \\
\text { mengenai } \\
\text { kebutuhan } \\
\text { ataupun } \\
\text { keinginannya. } \\
\text { Suami di unt } \\
\text { membutuhkan } \\
\text { pendamping di tua untuk } \\
\text { hari tua } \\
\text { berbagi suah } \\
\text { kebahagaiaan } \\
\text { Istri } \\
\text { mengenal suami } \\
\text { cukup lama } \\
\text { sehingga semakin } \\
\text { yakin dan mantap } \\
\text { untuk } \\
\text { menjadikan } \\
\text { suami sebagai } \\
\text { pasangan hidup } \\
\text { Suami } \\
\text { menunjukkan } \\
\text { niat baiknya } \\
\text { kepada istri sejak } \\
\text { pertama kali } \\
\text { bertemu Kembali } \\
\text { sehingga istri } \\
\text { semakin yakin. }\end{array}$ \\
\hline $\begin{array}{l}\text { Komitmen } \\
\text { jangka anjang } \\
\text { (keinginan } \\
\text { mempertahankan } \\
\text { hubungan } \\
\text { perkawinan) }\end{array}$ & 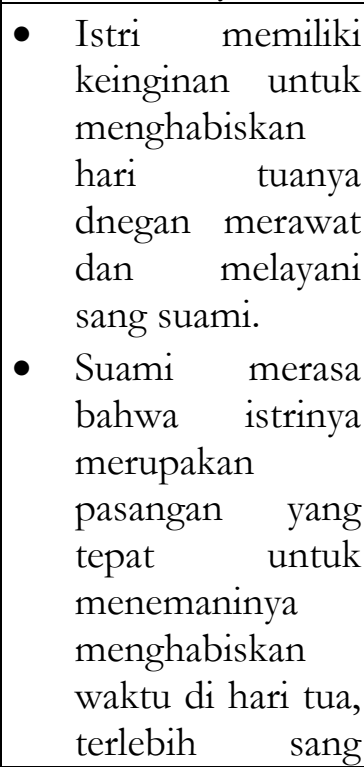 \\
\hline
\end{tabular}




\begin{tabular}{|c|c|}
\hline & $\begin{array}{lr}\text { suami } & \text { memiliki } \\
\text { rasa } & \text { sayang } \\
\text { kepada } & \text { istri sejak } \\
\text { dulu } & \end{array}$ \\
\hline Harapan & 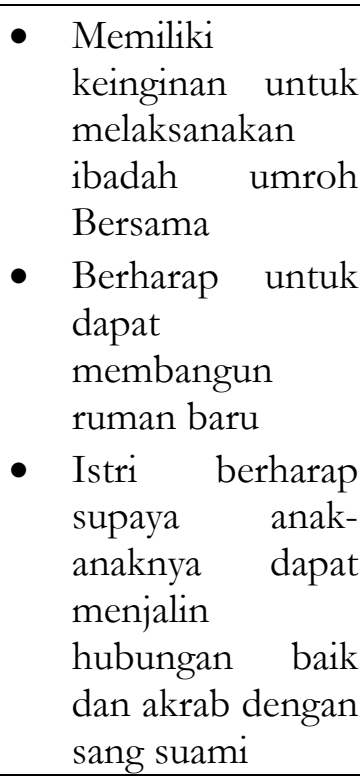 \\
\hline $\begin{array}{l}\text { Penerimaan diri } \\
\text { positif }\end{array}$ & $\begin{array}{l}\text { - } \text { Tekad sang suami } \\
\text { untuj menikahi } \\
\text { dan memilih NS } \\
\text { sebagai pasangan } \\
\text { hidup menjadikan } \\
\text { NS percaya diri } \\
\text { bahwa } \\
\text { merupakan } \\
\text { seseorang yang } \\
\text { pantas untuk } \\
\text { menjadi istri bagi } \\
\text { suaminya }\end{array}$ \\
\hline $\begin{array}{l}\text { Munculnya } \\
\text { masalah }\end{array}$ & $\begin{array}{l}\text { - Kurangnya restu } \\
\text { yang didapat dari } \\
\text { anak Ketika akan } \\
\text { menikah, } \\
\text { menjadikan anak- } \\
\text { anak dari sang } \\
\text { istri kurang } \\
\text { pedulu terhadap } \\
\text { hubungan mereka } \\
\text { - Sang suami } \\
\text { pernah diancam } \\
\text { dan diminta oleh } \\
\text { anak istrinya }\end{array}$ \\
\hline
\end{tabular}

\begin{tabular}{|l|l|}
\hline & $\begin{array}{l}\text { untuk berpisah } \\
\text { dan menjauhi } \\
\text { sang istri }\end{array}$ \\
\hline
\end{tabular}

Tabel 2. Komponen dan Elemen Hubungan Romantis yang Muncul pada Pasangan

\begin{tabular}{|c|c|}
\hline $\begin{array}{c}\text { Komponen \& } \\
\text { Elemen }\end{array}$ & Keterangan \\
\hline $\begin{array}{l}\text { Keintiman } \\
\text { (meningkatkan } \\
\text { kesejahteraan } \\
\text { pasangan) }\end{array}$ & $\begin{array}{l}\text { - } \text { Suami mewujudkan } \\
\text { keinginan sitri } \\
\text { untuk membangun } \\
\text { rumah }\end{array}$ \\
\hline $\begin{array}{l}\text { Keintiman } \\
\text { (merasakan } \\
\text { adanya } \\
\text { kesenangan } \\
\text { dan } \\
\text { kegembiraan) }\end{array}$ & $\begin{array}{l}\text { - Merasakan } \\
\text { kebahagiaan } \\
\text { apabila selalu } \\
\text { melakukan aktivitas } \\
\text { bersama bahkan } \\
\text { bekerja pun juga } \\
\text { bersama-sama }\end{array}$ \\
\hline $\begin{array}{l}\text { Keintiman } \\
\text { (mampu } \\
\text { menghormati } \\
\text { pasangan) }\end{array}$ & $\begin{array}{ll}\text { - Istri selalu } \\
\text { menghargai suami } \\
\text { Ketika sang suami } \\
\text { sedang merasa } \\
\text { Lelah atau memiliki } \\
\text { banyak pikiran } \\
\text { dengan } \\
\text { memberikan waktu } \\
\text { sendiri bagi sang } \\
\text { suami } \\
\text { - Suami melindungi } \\
\text { martabat dan harga } \\
\text { diri sang istri Ketika } \\
\text { mendapat fitnah } \\
\text { dari tetangga }\end{array}$ \\
\hline $\begin{array}{l}\text { Keintiman } \\
\text { (mampu } \\
\text { mengandalkan } \\
\text { pasangan) }\end{array}$ & $\begin{array}{l}\text { - } \text { Ketika istri } \\
\text { berhalangan untuk } \\
\text { memenuhi } \\
\text { tugasnya berdagang } \\
\text { di pasar, istri } \\
\text { mampu } \\
\text { mengandalkan sang } \\
\text { suami untuk } \\
\text { menggantikan } \\
\text { posisinya terlebih } \\
\text { dahulu, sehingga } \\
\end{array}$ \\
\hline
\end{tabular}




\begin{tabular}{|c|c|}
\hline & $\begin{array}{lr}\begin{array}{l}\text { kepercayaan } \\
\text { kepada }\end{array} & \text { istri } \\
\text { cukuap baik } & \\
\end{array}$ \\
\hline $\begin{array}{l}\text { Keintiman } \\
\text { (memahami } \\
\text { kelebihan dan } \\
\text { kelemahan } \\
\text { pasangan) }\end{array}$ & $\begin{array}{l}\text { - Ketika sama-sama } \\
\text { sedang lelah, baik } \\
\text { suami maupun istri } \\
\text { memberikan waktu } \\
\text { sendiri dan } \\
\text { menyuruh } \\
\text { pasangan untuk } \\
\text { beristirahat terlebih } \\
\text { dahulu } \\
\text { Menurut sang istri, } \\
\text { suami merupakan } \\
\text { seorang yang } \\
\text { mandiri, sehingga ia } \\
\text { sering membantu } \\
\text { sang istri dalam } \\
\text { menyelesaikan } \\
\text { pekerjaan rumah } \\
\text { tangga terlebih } \\
\text { Ketika sang istri } \\
\text { sedang merasa } \\
\text { kelelahan }\end{array}$ \\
\hline $\begin{array}{l}\text { Keintiman } \\
\text { (membagi } \\
\text { waktu dan } \\
\text { harta) }\end{array}$ & 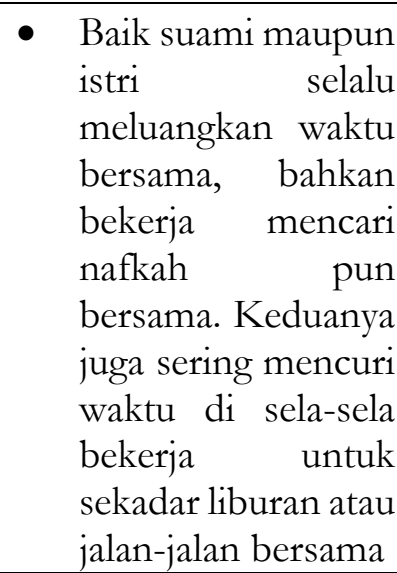 \\
\hline $\begin{array}{l}\text { Keintiman } \\
\text { (mendapatkan } \\
\text { dukungan } \\
\text { emosional dari } \\
\text { pasangan) }\end{array}$ & $\begin{array}{lrr}\text { - Istri } & \text { ikut } \\
\text { memberikan } & \text { solusi } \\
\text { Ketika r suami } & \text { sualah } \\
\text { memiliki masala } & \text { yang cukup berat } \\
\text { dan } & \text { menjadi } \\
\text { pendengar yang } \\
\text { baik bagi } & \text { sang } \\
\text { suami } & \\
\text { - Suami memberikan } \\
\text { waktu sendiri bagi } \\
\text { sang } & \text { istri, }\end{array}$ \\
\hline
\end{tabular}

\begin{tabular}{|c|c|}
\hline & $\begin{array}{l}\text { memberikan } \\
\text { perkataan yang } \\
\text { menenangkan, dan } \\
\text { menyuruhnya } \\
\text { beristirahat Ketika } \\
\text { sang istri sedang } \\
\text { memiliki masalah } \\
\text { ataupun sedang } \\
\text { merasa kelelahan. }\end{array}$ \\
\hline $\begin{array}{l}\text { Keintiman } \\
\text { (menciptakan } \\
\text { komunikasi } \\
\text { yang intim } \\
\text { dengan } \\
\text { pasangan) }\end{array}$ & 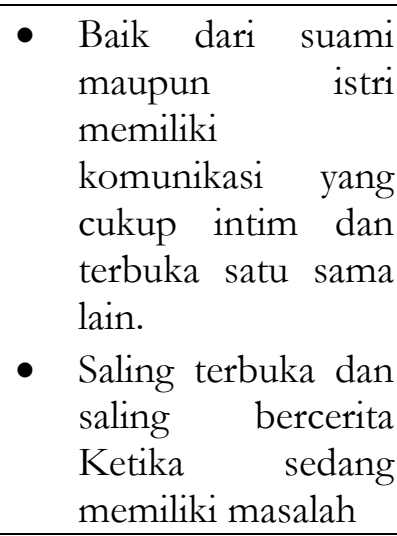 \\
\hline $\begin{array}{l}\text { Hasrat (hasrat } \\
\text { untuk bersatu) }\end{array}$ & $\begin{array}{lr}\text { - } & \text { Suami memiliki } \\
\text { keinginan untuk } \\
\text { terus bersama } \\
\text { dengan istri karena } \\
\text { sudah merasa } \\
\text { nyaman dan cocok } \\
\text { - } \text { Berusaha untuk } \\
\text { terus menciptakan } \\
\text { hubungan yang } \\
\text { baik dengan anak } \\
\text { dari pasangan }\end{array}$ \\
\hline $\begin{array}{l}\text { Hasrat } \\
\text { (hubungan } \\
\text { seksual) }\end{array}$ & 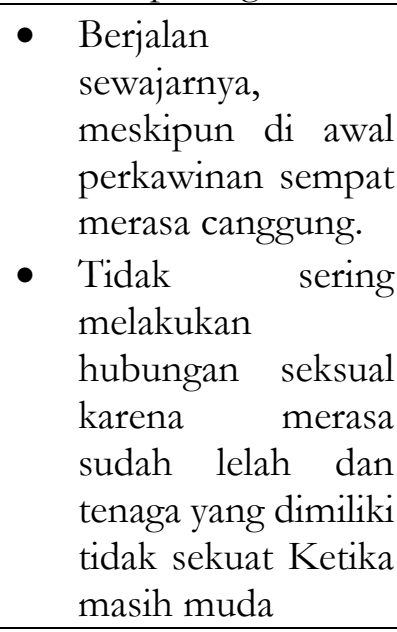 \\
\hline $\begin{array}{l}\text { Komitmen } \\
\text { jangka pendek }\end{array}$ & $\begin{array}{l}\text { - Suami } \\
\text { mengenal }\end{array}$ \\
\hline
\end{tabular}




\begin{tabular}{|c|c|}
\hline $\begin{array}{l}\text { (dorongan } \\
\text { menjalin } \\
\text { hubungan } \\
\text { perkawinan } \\
\text { dan alas an } \\
\text { memilih } \\
\text { pasangan } \\
\text { sebagai } \\
\text { pendamping } \\
\text { hidup_ }\end{array}$ & $\begin{array}{l}\text { mengetahui sifat } \\
\text { istri, sehingga } \\
\text { semakin yakin } \\
\text { untuk menikai sang } \\
\text { istri } \\
\text { - Suami juga } \\
\text { terdorong untuk } \\
\text { menikah karena } \\
\text { merasa terganggu } \\
\text { dengan perjodohan } \\
\text { yang dilakukan oleh } \\
\text { para tetangganya } \\
\text { Membutuhkan } \\
\text { teman di hari tua } \\
\text { untuk dapat saling } \\
\text { merawat, berbagi } \\
\text { cerita, berbagi } \\
\text { masalah, dan } \\
\text { menghabiskan } \\
\text { waktu bersama } \\
\text { Istri membutuhkan } \\
\text { pendamping hidup } \\
\text { untuk menghindari } \\
\text { zina dan fitnah } \\
\text { karena merasa } \\
\text { status janda cukup } \\
\text { sensitive dalam } \\
\text { penilaian orang lain } \\
\text { Istri menginginkan } \\
\text { Kembali hadirnya } \\
\text { sosok imam bagi } \\
\text { dirinya }\end{array}$ \\
\hline $\begin{array}{l}\text { Komitmen } \\
\text { jangka panjang } \\
\text { (keinginan } \\
\text { mempertahank } \\
\text { an hubungan } \\
\text { perkawinan) }\end{array}$ & $\begin{array}{l}\text { - Suami selalu ingin } \\
\text { bersama dengan } \\
\text { istri karena hal } \\
\text { tersebut } \\
\text { merupakan sesuatu } \\
\text { yang } \\
\text { membahagiakan } \\
\text { baginya }\end{array}$ \\
\hline Harapan & 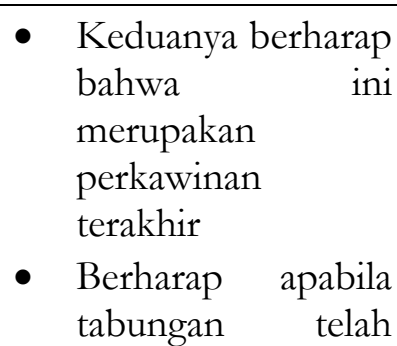 \\
\hline
\end{tabular}

\begin{tabular}{|c|c|}
\hline & $\begin{array}{l}\text { terkumpul dapat } \\
\text { melaksanakan } \\
\text { ibadah umroh } \\
\text { bersama } \\
\text { istri berharap } \\
\text { pekerjaanya dengan } \\
\text { sang suami dapat } \\
\text { berjalan lancer, } \\
\text { dagangan laris } \\
\text { sesuai dengan } \\
\text { harapan karena } \\
\text { tidak ingin } \\
\text { menggantunngkan } \\
\text { pendapatan dari } \\
\text { sang anak saja }\end{array}$ \\
\hline $\begin{array}{l}\text { Penerimaan } \\
\text { diri positif }\end{array}$ & $\begin{array}{l}\text { - Istri memiliki } \\
\text { penerimaan diri } \\
\text { yang positif karena } \\
\text { sang suami dapat } \\
\text { menerima dirinya } \\
\text { apa adanya, } \\
\text { sehingga } \\
\text { menjadikannya } \\
\text { puas atas hubungan } \\
\text { yang dimiliki } \\
\text { dengan suami } \\
\end{array}$ \\
\hline $\begin{array}{l}\text { Munculnya } \\
\text { masalah }\end{array}$ & 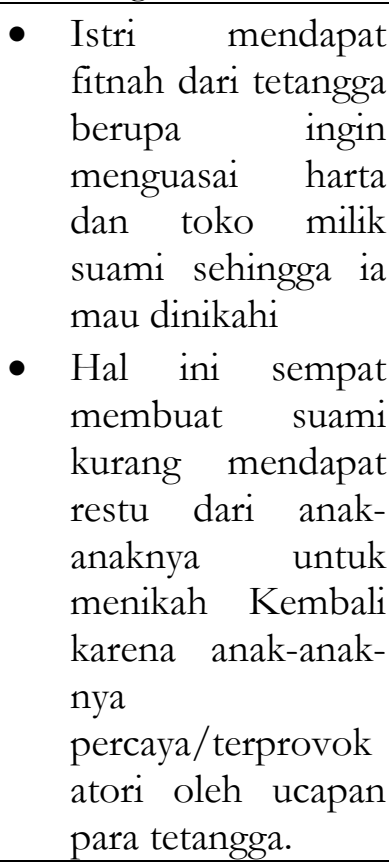 \\
\hline
\end{tabular}


Tabel 3. Komponen dan Elemen Hubungan Romantis yang Muncul pada Pasangan 3

\begin{tabular}{|c|c|}
\hline $\begin{array}{c}\text { Komponen \& } \\
\text { Elemen }\end{array}$ & Keterangan \\
\hline $\begin{array}{l}\text { Keintiman } \\
\text { (meningkatkan } \\
\text { kesejahteraan } \\
\text { pasangan) }\end{array}$ & $\begin{array}{l}\text { - Suami selalu } \\
\text { menuruti keinginan } \\
\text { dan kemauan istri, } \\
\text { seperti sering } \\
\text { mengajak istri } \\
\text { jangan-jalan karena } \\
\text { jalan-jalan } \\
\text { merupakan hobi } \\
\text { sang istri sebagai } \\
\text { penghilang penat }\end{array}$ \\
\hline $\begin{array}{l}\text { Keintiman } \\
\text { (merasakan } \\
\text { adanya } \\
\text { kesenangan dan } \\
\text { kegembiraan) }\end{array}$ & $\begin{array}{l}\text { - Suami merasa } \\
\text { senang dengan } \\
\text { bentuk perhatian } \\
\text { yang diberikan oleh } \\
\text { sang istri, berupa } \\
\text { rajin merawat } \\
\text { suami, menyiapkan } \\
\text { keperluan suami, } \\
\text { dan memasak } \\
\text { makanan favorit } \\
\text { suami } \\
\text { - Istri selalu ada } \\
\text { untuk sang suami, } \\
\text { sehingga suami } \\
\text { tidak merasa } \\
\text { kesepian lagi }\end{array}$ \\
\hline $\begin{array}{l}\text { Keintiman } \\
\text { (mampu } \\
\text { menghormati } \\
\text { pasangan) }\end{array}$ & $\begin{array}{l}\text { - Suami menghargai } \\
\text { keputusan istri } \\
\text { yang enggan } \\
\text { melakukan } \\
\text { hubungan seksual } \\
\text { - Suami menghargai } \\
\text { keputusan sang } \\
\text { istri yang enggan } \\
\text { untuk memiliki } \\
\text { hubungan dekat } \\
\text { dengan karena } \\
\text { keluarganya kara kurang } \\
\text { istri respon } \\
\text { mendapat } \\
\text { yang baik dari }\end{array}$ \\
\hline
\end{tabular}

\begin{tabular}{|c|c|}
\hline & $\begin{array}{l}\text { keluarga besar sang } \\
\text { suami }\end{array}$ \\
\hline $\begin{array}{l}\text { Keintiman } \\
\text { (memahami } \\
\text { kelebihan dan } \\
\text { kelemahan } \\
\text { pasangan) }\end{array}$ & $\begin{array}{l}\text { - Menurut suami, } \\
\text { sang istri memiliki } \\
\text { kelebihan berupa } \\
\text { mudah bangkit dari } \\
\text { kesedihan atau } \\
\text { keterpurukan, dan } \\
\text { selalu mengambil } \\
\text { hikmah serta sisi } \\
\text { positif dari masalah } \\
\text { yang pernah } \\
\text { dialami }\end{array}$ \\
\hline $\begin{array}{l}\text { Keintiman } \\
\text { (membagi waktu } \\
\text { dan harta) }\end{array}$ & $\begin{array}{lc}\text { - } \begin{array}{l}\text { Pengelolaan } \\
\text { atau uang }\end{array} & \text { harta } \\
\text { sepenuhnya } & \\
\text { dilakukan } & \text { oleh } \\
\text { sang istri } & \\
\text { - Baikm } & \text { suami } \\
\text { maupun istri } \\
\text { terbuka dengan } \\
\text { harta yang dimiliki } \\
\end{array}$ \\
\hline $\begin{array}{l}\text { Keintiman } \\
\text { (mendapatkan } \\
\text { dukungan } \\
\text { emosional dari } \\
\text { pasangan) }\end{array}$ & $\begin{array}{l}\text { - Suami selalu } \\
\text { memberikan } \\
\text { ucapan atau } \\
\text { perkataan yang } \\
\text { menenangkan } \\
\text { Ketika istri sedang } \\
\text { memiliki masalah, } \\
\text { terutama Ketika } \\
\text { berkumoul dengan } \\
\text { keluarga suami dan } \\
\text { istri merasa } \\
\text { dikucilkan }\end{array}$ \\
\hline \multirow[t]{2}{*}{$\begin{array}{l}\text { Hasrat (Hasrat } \\
\text { untuk Bersatu) }\end{array}$} & 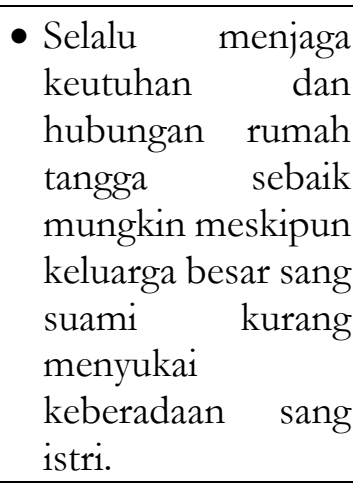 \\
\hline & $\begin{array}{l}\text { - Sudah bersepakat } \\
\text { tidak melakukan } \\
\text { hubungan seksual }\end{array}$ \\
\hline
\end{tabular}




\begin{tabular}{|c|c|}
\hline & $\begin{array}{l}\text { karena sang istri } \\
\text { kurang percaya diri } \\
\text { dengan bentuk } \\
\text { tubun yang dimiliki } \\
\text { setelah melakukan } \\
\text { mastektomi atau } \\
\text { operasi } \\
\text { pengangkatan } \\
\text { payudara }\end{array}$ \\
\hline $\begin{array}{l}\text { Komitmen } \\
\text { jangka pendek } \\
\text { (dorongan } \\
\text { menjalin } \\
\text { hubungan } \\
\text { perkawinan dan } \\
\text { alas an memilih } \\
\text { pasangan sebagai } \\
\text { pendamping } \\
\text { hidup) }\end{array}$ & $\begin{array}{l}\text { - Suami terdorong } \\
\text { untuk melakukan } \\
\text { perkawinan } \\
\text { Kembali karena } \\
\text { merasa kesepian } \\
\text { setelah tidak } \\
\text { memiliki pasangan } \\
\text { - Suami un } \\
\text { membutuhkan } \\
\text { teman untuk } \\
\text { berbagi cerita atau } \\
\text { teman mengobrol } \\
\text { - Suami merasa } \\
\text { kurang nyaman } \\
\text { apabila dirawat } \\
\text { oleh anak menantu } \\
\text { perempuannya } \\
\text { - Baik suami } \\
\text { maupun istri sama- } \\
\text { sama memenuhi } \\
\text { kriteria pasangan } \\
\text { Ketika akan } \\
\text { menikah Kembali } \\
\text { - Istri terdorong } \\
\text { untuk melakukan } \\
\text { perkawinan } \\
\text { Kembali karena } \\
\text { membutuhkan } \\
\text { sosok pelindung } \\
\text { dalam hidupnya } \\
\text { dan menghindari } \\
\text { zina atau fitnah } \\
\text { atas status janda } \\
\text { yang dimiliki }\end{array}$ \\
\hline $\begin{array}{l}\text { Komitmen } \\
\text { jangka Panjang } \\
\text { (keinginan }\end{array}$ & $\begin{array}{l}\text { - Suami tidak ingin } \\
\text { merasa kesepian } \\
\text { hingga } \\
\text { menyebabkan }\end{array}$ \\
\hline
\end{tabular}

\begin{tabular}{|c|c|}
\hline $\begin{array}{l}\text { mempertahankan } \\
\text { hubungan) }\end{array}$ & $\begin{array}{l}\text { stress di hari } \\
\text { tuanya, sehingga ia } \\
\text { membutuhkan } \\
\text { teman hidup untuk } \\
\text { selalu di } \\
\text { sampingnya. } \\
\text { - Di hari tuanya, sitri } \\
\text { ingin } \\
\text { menghabiskan } \\
\text { waktu untuk } \\
\text { mengabdi pada } \\
\text { suami dan melayani } \\
\text { serta merawat } \\
\text { suami, karena } \\
\text { baginya } \\
\text { tersebut hal } \\
\text { merupakan ladang } \\
\text { pahala }\end{array}$ \\
\hline & • \\
\hline \multirow[t]{2}{*}{ Harapan } & 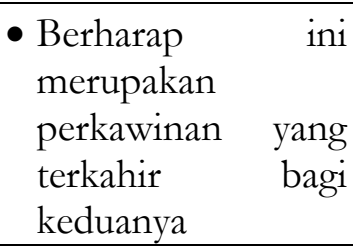 \\
\hline & $\begin{array}{l}\text { - Istri berharap agar } \\
\text { dapat selalu ikhlas } \\
\text { atas penilaian dan } \\
\text { sikap yang } \\
\text { diberikan keluarga } \\
\text { besar suami kepada } \\
\text { dirinya. } \\
\text { - Berharap memiliki } \\
\text { kesempatan untuk } \\
\text { dapat melalukan } \\
\text { perjalanan liburan } \\
\text { ke luar negeri } \\
\text { bersama } \\
\text { - Berharap anak dan } \\
\text { cucu selalu } \\
\text { diberikan } \\
\text { Kesehatan dan } \\
\text { hidup rukun }\end{array}$ \\
\hline $\begin{array}{l}\text { Munculnya } \\
\text { masalah }\end{array}$ & $\begin{array}{lr}\text { - } \begin{array}{l}\text { Keluarga } \\
\text { suami }\end{array} & \text { besar } \\
\text { menyukai } & \\
\begin{array}{l}\text { keberadaan } \\
\text { bahkan }\end{array} & \text { istri } \\
\end{array}$ \\
\hline
\end{tabular}




\begin{tabular}{|l|lr|}
\hline & \multicolumn{2}{|c|}{ mengucilkan sang } \\
istri telah memiliki \\
komunikasi dengan \\
suamirrar jauh \\
sebelum ristri \\
pertamar suami \\
meninggal dunia \\
- Suami sempat tidak \\
mendapat restu \\
dari anak-anaknya \\
untuk r menikah \\
kembali
\end{tabular}

Berdasarkan hasil penelitian, hubungan romantis dimaknai oleh ketiga pasangan dengan menunjukkan adanya jalinan keintiman, hasrat, dan komitmen seperti yang dirumuskan oleh Sternberg (1997), selain itu juga menciptakan harapan bersama, penerimaan diri yang bersifat positif, dan munculnya masalah. Pada tiap pasangan menunjukkan munculnya komponen hubungan romantis dan contoh perilaku yang berbeda-beda. Hal ini dapat terjadi karena adanya pengaruh perbedaan usia perkawinan maupun kesepakatan dan kebiasaan yang dibentuk.

Keintiman sangat penting penting dibangun dalam menjalin hubungan suami istri, terlebih ketika sudah memasuki usia lanjut. Hal ini sejalan dengan pendapat Tiikkainen, dkk (dalam Gupta, 2015) bahwa kurangnya hubungan intiman adalah salah satu faktor utama munculnya perasaan kesepiaan. Perasaan kesepian juga cenderung meningkat seiring bertambahnya usia terlebih apabila tidak terlibat dalam hubungan intim dengan orang lain (Gupta, 2015).

Mengenai keintiman, ketiga pasangan menunjukkan perilaku tersebut dengan mewujudkan keinginan pasangan, memuji kecantikan pasangan, memberikan bunga favorit kepada pasangan, merawat ketika sakit, menghabiskan waktu dengan beraktivitas bersama, saling menghormati, saling memberikan dukungan emosional, dan saling berbagi harta. Beberapa perilaku di atas sejalan dengan hasil penelitian yang dilakukan oleh Gupta, dkk (2015) bahwa pasangan lansia Afrika-Amerika pun menunjukkan jalinan cinta dan keromantisan kepada pasangan dengan saling menghormati, saling mernghargai, dan saling membantu antar pasangan.

Stinnett (1984: 47) juga berpendapat bahwa seseorang yang memiliki keinginan untuk bersama dengan orang yang dicinta dengan memenuhi kebutuhan dasar seperti kebutuhan akan harga diri, kasih sayang, rasa hormat, dan kepercayaan. Hal ini sesuai dengan perilaku yang ditunjukkan oleh ketiga pasangan suami istri lansia, kecuali pada pemenuhan kebutuhaan akan kepercayaan yang diberikan kepada pasangan. Pada bagian ini, kepercayaan antar pasangan hanya tercipta pada pasangan kedua saja ( $\mathrm{J}$ dan $\mathrm{BJ}$ ) yang memiliki hubungan perkawinan paling tua diantara ketiga pasangan. Bentuk keterbukaan komunikasi secara intim ditunjukkan dengan cara saling berbagi dan terbuka mengenai masalah yang sedang dialami satu sama lain, sedangkan pada pasangan pertama dan ketiga keterbukaan komunikasi yang intim mengenai masalah yang dimiliki belum terjalin sepenuhnya.

Bentuk hubungan romantis selanjutnya yang ditunjukkan pada penelitian ini adalah adanya hasrat dalam bentuk ketertarikan melalui fisik maupun seksual kepada pasangan (Sternberg, 1997). Jalinan hubungan seksual atau hubungan suami istri masih dilakukan oleh pasangan suami istri lansia pertama dan kedua. Hal ini sesuai dengan yang dipaparkan oleh Suardiman (2011: 37) walaupun organ reproduksi pada lansia menurun, dorongan untuk melakukan hubungan sesksual pada lansia belum sepenuhnya menurun.

Tidak adanya hubungan seksual pada pasangan ketiga merupakan kesepakatan yang telah dibentuk baik dari suami maupun istri. Hal ini dilakukan karena sang istri kurang memiliki kepercayaan diri atas tampilan fisik bagian payudaranya setelah melakukan mastektomi. Meskipun dorongan untuk 
melakukan hubungan sesksual pada usia lanjut belum sepenuhnya menurun, namun menurut Syah dan Mulyadi (2016: 50) seseorang yang melakukan perkawinan di usia lanjut menganggap bahwa hubungan seksual bukanlah suatu hal yang penting. Ketidakseimabngan antara kekuatan fisik dan minat seksual membuat seorang lansia akan mencari bentuk aktivitas lain bersama dengan pasangan yang dapat memenuhi hasrat seksualnya daripada memaksakan untuk berhubungan.

Dorongan untuk menjalin hubungan dengan orang yang dicinta juga dimaknai oleh subjek dengan keinginan untuk membangun jalinan persahabatan dengan pasangan. Pada hal ini reuni ternyata berperan andil dalam membantu subjek untuk menemukan pasangannya dan melaksanakan perkawinan kembali meskipun di usia yang sudah lanjut, karena dua dari tiga pasangan yang menjadi subjek penelitian yaitu pasangan pertama dan ketiga bertemu dengan pasangannya melalui acara reuni SD dan SMP. Membangun jalinan persahabatan termasuk bentuk hubungan romantis pada lansia. Hal ini sejalan dengan pendapat Silva, dkk (2019: 6) bahwa terciptanya sebuah persahabatan dalam perkawinan di usia lanjut dapat terjadi karena adanya hubungan saling merawat dan saling memahami satu sama lain. Hasil penelitian Gupta, dkk (2015: 12) juga menyebutkan bahwa lansia AfrikaAmerika menggambarkan jalinan cinta romantis dalam bentuk membangun hubungan persahabatan dengan pasangan.

$$
\text { Munculnya bentuk jalinan }
$$

hubungan romantis juga ditunjukkan dengan terciptanya harapan antara suami dan istri. Harapan yang diciptakan bersama dengan pasangan dapat mempererat hubungan, karena adanya keinginan untuk merealisasikan harapan tersebut menjadi kenyataan. Penjelasan tersebut sesuai dengan pendapat dari Hendrick (1988) bahwa harapan dapat mewujudkan dan mendorong sesorang serta pasangannya untuk mempertahankan hubungan yang telah dibangun melalui perencanaan dan kesekapakatan yang dibentuk. Ketiga pasangan menunjukkan adanya harapan yang dibangun bersama dengan keinginan untuk melaksanakan ibadah umroh bersama, berlibur bersama, dapat membangun rumah baru, serta menciptakan hubungan yang baik dan akrab dengan anak-anak serta keluarga

Masalah yang Muncul dalam Hubungan Perkawinan yang dilakukan di Usia Lanjut

Miller (2015) menyatakan bahwa adanya masalah pada dasarnya dapat mendewasakan seseorang dalam menjalin hubungan apabila dapat diatasi dengan baik dan tepat, seperti memiliki kesediaan untuk berlatih mengatasinya hingga menemukan cara yang tepat untuk menyelesaikan masalah tersebut. Menurut Hendrick (1988) apabila masalah dapat diatasi dengan baik, maka dapat meminimalisir konflik yang terjadi dalam hubungan romantis.

Masalah yang muncul pada perkawinan yang dilakukan di usia lanjut berupa kurangnya restu dari anak maupun keluarga besar untuk melangsungkan perkawinan kembali, prasangka kurang baik dari keluarga terhadap salah satu pasangan, dan lingkungan sekitar yang memiliki penilaian kurang baik mengenai perkawinan di usia lanjut. Hurlock (dalam Hilda \& Suwarti, 2017) mengemukakan mengenai empat aspek dalam penyesuaian perkawinan, salah satunya ialah penyesuaian dengan pihak keluarga pasangan. Pada hal ini individu yang menikah harus mempelajari dan menyesuaikan diri dengan pihak keluarga pasangan bila individu tidak menginginkan hubungan yang tegang dengan sanak saudara mereka. Maka dari itu perlunya penyesuaian dengan keluarga lebih dalam pada subjek pasangan pertama dan ketiga yang hingga proses pengambilan data dilakukan memiliki hubungan yang kurang baik dengan anak dan keluarga pasangan. 
Komponen dan Elemen yang berkontribusi Mengatasi Masalah

Komponen dan elemen yang paling berkontribusi dalam mengatasi masalah yang muncul ialah komponen keintiman elemen mampu mensejahterakan pasangan dan menghormati pasangan, serta komponen komitmen aspek jangka pendek dan aspek jangka panjang. Komponen di atas berkontribusi karena subjek saling berusaha untuk mempertahankan hubungan mereka dan mengingat kembali tujuan menikah untuk mendapatkan kebahagiaan, serta menciptakan rasa saling menghormati dan memenuhi keinginan pasangan untuk mengatasi masalah yang terjadi.

Komponen komitmen memiliki peran besar dalam penyelesaian masalah yang terjadi di hubungan perkawinan di usia lanjut. Hal ini sesuai dengan yang dinyatakan oleh Finkel, Rusbult, Kumashiro, \& Hannon (2002) bahwa komitmen merupakan hal fundamental dalam suatu hubungan, terlebih dalam hubungan romantis yang melibatkan perasaan berlebih yaitu cinta, misalnya dalam hubungan perkawinan.

Pernyataan yang sama juga terdapat pada hasil penelitian yang dilakukan oleh Syah dan Mulyadi (2016:51) bahwa adanya komitmen dalam hubungan suami istri sebagai faktor suatu perkawinan dapat bertahan dalam menghadapi suatu masalah yang mungkin dapat tercipta dalam hubungan perkawinan. Selain itu apabila sebuah perkawinan didasari pada rasa cinta dan komitmen, maka pasangan akan lebih merasa bahagia.

\section{Dinamika Psikologis Lansia}

Lansia yang melakukan perkawinan di usia lanjut mengalami dinamika psikologis dilihat dari sisi hubungan romantis dengan pasangannya. Dua dari tiga pasangan yang menjadi responden penelitian menyatakan bahwa sebelum melakukan perkawinan kembali melakukan proses kencan. Proses kencan tersebut dilalui dengan menghabiskan waktu untuk berpergian bersama. Proses kencan dilakukan dengan tujuan menunggu restu dari anak-anak untuk dapat melangkah ke jenjang pernikahan.

Setelah menikah lansia saling memberikan perhatian satu sama lain dengan pasangannya, seperti sering memberikan bunga favorit pasangan, merawat pasangan ketika sakit, memenuhi keperluan atau kebutuhan pasangan seharihari dan menghabiskan waktu bersamasama. Hal ini dilakukan untuk mensejahterakan pasangan dan membahagiakan pasangan.

Meskipun usia lanjut identik dengan berbagai macam kemunduran seperti mengalami kesulitan dalam mengekspresikan secara verbal, namun pada kenyataannya hal ini tidak selalu dialami oleh lansia. Terdapat pasangan yang dapat menunjukkan kelebihan yang dimiliki oleh pasangannya, seperti sering memuji paras fisik kecantikan pasangan, maupun memuji perilaku pasangan yang bernilai positif. Bahkan pada pasangan pertama, sang suami sering menunjukkan respon atau perilaku cemburu, seperti marah dan mendiamkan sang istri apabila melihat sang istri melakukan komunikasi dengan teman laki-laki.

Selain mengetahui kelebihan yang dimiliki, responden juga mengetahui kelemahan yang dimiliki oleh pasangan. Satu dari ketiga pasangan yang menjadi responden juga menunjukkan adanya bentuk dukungan emosional satu sama lain secara intens, apabila salah satu pasangan sedang memiliki masalah. Bentuk dukungan tersebut berupa memberikan ucapan yang menenangkan, membiarkan pasangan untuk beristirahat, dan membantu menyelesaikan pekerjaannya.

Dukungan emosional tidak selalu ditunjukkan oleh pasangan pertama dan ketiga karena kurangnya keterbukaan komunikasi yang intim mengenai permasalahan atau kondisi yang sedang dialami. Kepercayaan belum sepenuhnya 
hadir dalam hubungan perkawina pada pasangan pertama dan ketiga. Hal ini terjadi karena usia perkawinan pada pasangan pertama dan ketiga yang tergolong masih muda. Bahkan salah satu pasangan mengatakan hanya ingin berbagi kebahagiaan saja dengan pasangan, tanpa 'dibumbui' adanya berbagi masalah pribadi.

Adapun segi hubungan seksual, walaupun organ reproduksi pada lansia menurun, dorongan untuk melakukan hubungan seksual belum tentu menurun. Pada pasangan pertama dan kedua masih terdapat hasrat untuk melakukan hubungan seksual, meskipun tidak dilakukan secara intens karena responden mengatakan bahwa tenaga yang dimiliki sudah tidak sekuat ketika masih muda dan mudah merasa lelah. Sementara itu pada pasangan ketiga tidak terdapat hubungan seksual karena sang istri merasa tidak percaya diri dengan bentuk fisiknya pada bagian payudara setelah melakukan mastektomi. Sang istri tidak ingin menunjukkan kelemahan tersebut kepada suaminya. Sang istri juga merasa takut apabila suatu saat nanti suaminya akan memberi tahu orang lain mengenai bentuk fisiknya yang menurutnya sudah tidak lagi sempurna. Namun tidak adanya hubungan seksual pada pasangan ketiga merupakan kesepakatan antara keduanya, sehingga sang suami pun akhirnya menghargai dan menghormati keputusan sang istri.

\section{Simpulan dan Saran}

Berdasarkan hasil penelitian dan pembahasan, maka diperoleh beberapa simpulan. Simpulan-simpulan tersebut yaitu omponen dan elemen hubungan romantis yang muncul pada hubungan perkawinan yang dilakukan di usia lanjut meliputi komponen keintiman, hasrat, komitmen, harapan, penerimaan diri positif, dan terciptanya masalah.

Selanjutnya, masalah yang muncul dalam perkawinan yang dilakukan di usia lanjut berasal dari berbagai macam faktor seperti sulitnya mendapat restu dari anak, dan munculnya stigma kurang baik dari kerabat atau lingkungan terdekat serta dari keluarga besar.

Komponen dan elemen yang paling berkontribusi dalam mengatasi masalah yang muncul dalam perkawinan di usia lanjut adalah komitmen dan upaya untuk mensejahterakan pasangan serta kemampuan menghormati pasangan.

Komponen dan elemen yang muncul tidak seluruhnya dirasakan oleh ketiga pasangan. Hal ini dapat terjadi karena adanya perbedaan usia perkawinan, adanya kesepakatan yang dibentuk, atau pun kebiasaan perilaku yang telah terbentuk.

Terdapat perbedaan orientasi melakukan perkawinan di usia lanjut antara lansia laki-laki dengan lansia perempuan. Lansia laki-laki membutuhkan sosok yang dapat merawat, melayani, teman bercerita, dan menjauhi rasa kesepian di hari tuanya setelah pasangan sebelumnya meninggal dunia. Adapun lansia perempuan memiliki orientasi melakukan perkawinan kembali karena ingin menghabiskan sisa hidupnya untuk mencari pahala dengan mengabdi, merawat, dan melayani atau memenuhi kebutuhan suami sehari-hari. Hadirnya sosok imam, pemimpin, pelindung, dan pendamping juga dibutuhkan lansia perempuan untuk menjauhkan dirinya dari zina dan fitnah atas status janda yang dimiliki sebelumnya. Lansia perempuan beranggapan bahwa status janda memiliki stigma yang kurang baik.

Ketiga pasangan menunjukkan bahwa perkawinan yang dilakukan di usia lanjut tidak hanya bertujuan untuk memenuhi hasrat atau minat seksual semata, akan tetapi lebih karena membutuhkan sosok pendamping hidup untuk saling merawat, menemani, dan teman bercerita di hari tua.

Bagi subjek diharapkan tetap mempertahankan sisi keromantisan, karena 
keromantisan dapat menyegarkan kembali hubungan perkawinan yang terkadang tercipta jarak di antara suami istri karena munculnya suatu masalah.

Bagi pasangan pertama dan ketiga diharapkan untuk dapat memperbanyak komunikasi secara intim dan terbuka mengenai keadaan yang sedang dialami. Hal ini dilakukan agar tidak terjadi suatu kesalahpahaman dalam proses komunikasi yang memungkinkan terciptanya suatu konflik.

Mampu memperbaiki dan menjalin hubungan yang baik serta kedekatan kembali dengan anak dan keluarga yang sampai pengambilan data pada penelitian ini dilakukan, masih terdapat masalah karena kurangnya restu dan pengenalan lebih jauh sebelum melakukan perkawinan kembali.

Peneliti selanjutnya diharapkan mampu meneliti lebih mendalam mengenai dinamika dan kualitas hubungan perkawinan pada lansia, serta dapat melakukan pengambilan data dengan keluarga lansia pula. Bagi peneliti yang ingin melakukan penelitian yang sama juga dapat melakukan penelitian dengan subjek yang memiliki lintas usia cukup jauh dengan pasangannya (hanya salah satu pasangan yang memasuki kriteria lansia).

\section{Daftar Pustaka}

Badan Pusat Statistik, 2015. Statistik Penduduk Lanjut Usia 2014. Jakarta: Badan Pusat.

Berlian, R., \& Heppy, F. (2014). Hubungan Depresi dengan Kejadian Insomnia pada Lansia di Panti Sosial Tresna Wredha Kasih Sayang Ibu Batusangkar. Jurnal Kesehatan Stikes Prima Nusantara Bukit Tinggi, 83.

Finkel, E. J., Rusbult, C. E., Kumashiro, M., \& Hannon, P. A. (2002). Dealing with betrayal in close relationships: Does Commitment Promote Forgiveness? Journal of Personality and Social Psychology, 82(6), 956-974. https://doi.org/10.1037/00223514.82.6.956.

Gupta, R., Pillai, V., Punetha, D., \& Monah, A. (2015). Love experiences of older African Americans: A qualitative study. Journal of International Women's Studies, 16(3), 277-293.

Hendrick, S. S. (1988). A generic measure of relationship satisfaction. Journal of Marriage and Family. 50, 93-98.

Hilda, Nunun. F., \& Suwarti. (2017). Studi Kasus Penyesuaian Perkawinan Pada Duda Lanjut Usia yang Menikah Lagi. Psycho Idea. Diakses pada 2 Februari 2019, http://jurnalnasional.ump.ac.id/in dex.php/ PSYCHOIDEA/article/view/244 $\underline{5}$

Kemenkes Republik Indonesia. (2017). Situasi lansia di Indonesia tabun 2017: Gambar struktur umur penduduk insonesia tahun 2017. Pusat Data Dan Informasi, 1--9.

Miller, R. S. (2015). Intimate Relationship: Seventh Edition. New York: McGraw-Hill Education.

Myers, David G. (2012). Psikologi Sosial Jilid 2. Jakarta: Salemba Humanika.

Papalia, E. D \& Feldman R. D. (2014). Menyelami Perkembangan Manusia: Experience Human Development. Jakarta: Salemba Humanika.

Putri, Nolan. A. K. (2017). Romantisme Pada Pasangan Lanjut Usia.

Skripsi. Universitas Muhammadiyah Surakarta.

Silva, E. P., Nogueira, I. S., Labegalini, C. M. G., De Munck, Victor C. (1998) Romantic Love and Sexual Behaviour: Perspectives from The Social Science. 
London: Greenwood Publishing

Group.

Carreira, L., \& Baldissera, V. D. A. (2019). Perceptions of care among elderly couples. Revista Brasileira de Geriatria e Gerontologia, 22(1). https://doi.org/10.1590/1981$\underline{22562019022.180136}$

Sternberg, R. J. (1997). Construct Validation of A Triangular Love Scale. European Journal of Social Psychology, 27(3), 313-335. https://doi.org/10.1002/(sici)1099 -0992(199705)27:3<313::aidejsp824>3.3.co;2-w.

Sternberg, Robert J. (2009). Cupid's $\backslash$ Arrow The Course of Love Through Time. Yogyakarta: Pustaka Pelajar.

Stinnett, Nick., James Walters., Evelyn K. (1984). Relationship in Marriage and The Family. US: Macmillan Publishing.

Suardiman, Siti. P. (2011). Psikologi Lanjut Usia. Yogyakarta: Gadjah Mada University Press.

Syah, Luthfi. A., \& Mulyadi. (2016). Motivasi Menikah Lagi: Studi Kasus Pasangan Suami Istri dari Seorang Janda dan Duda yang Menikah Lagi di Usia Lanjut. Jurnal Psikoislamika. Vol. 13, No. 2 (2016), 47-52.

Yung, E. H. K., Conejos, S., \& Chan, E. H. W. (2016). Social needs of the elderly and active aging in public open spaces in urban renewal. Cities, 52, 114-122. https://doi.org/10.1016/i.cities.201 $\underline{5.11 .022}$. 